Historic, archived document

Do not assume content reflects current scientific knowledge, policies, or practices. 

Donald K. Artley

Raymond C. Shearer

Robert W. Steele 
, 


\section{EFFECTS OF BURNING MOIST FUELS ON SEEDBED PREPARATION IN CUTOVER WESTERN LARCH FORESTS}

Donald K. Artley, Raymond C. Shearer, and Robert W. Steele 


\section{THE AUTHORS}

DONALD K. ARTLEY received a B.S. degree from Iowa State University in 1967, and an M.S. degree in Forest Fire Science from the University of Montana in 1977. He is presently employed as a forester with the Fire Management Bureau of the Montana Division of Forestry. This publication is based on his M.S. thesis.

RAYMOND C. SHEARER received a B.S. degree in Timber Management in 1957 and an M.S. degree in Silviculture in 1959, both from Utah State University. Currently he is completing requirements for the $\mathrm{Ph}$. D. in Forest Ecology at the University of Montana. Since 1957, he has been a Research Silviculturist, assigned to the Station's Silviculture of Northern Rocky Mountain Larch, Lodgepole Pine, and Spruce Ecosystems research work unit at the Forestry Sciences Laboratory in Missoula, Montana. His primary assignment has been the study of natural and artificial regeneration of western larch and associated species.

ROBERT W. STEELE received a B.S. degree in forestry from Colorado State University in 1942, an M.F. degree from the University of Michigan in 1949, and the Ph. D. in Forest Fire Science from Colorado State University in 1975. He is currently professor of Forest Fire Science at the School of Forestry, University of Montana. 


\section{CONTENTS}

Page

INTRODUCTION . . . . . . . . . . . . . . . . 1

LITERATURE . . . . . . . . . . . . . . . 2

STUDY AREA AND TREATMENT . . . . . . . . . . . 2

METHODS ................... 5

Duff Reduction and Mineral Soil Exposure... . . . . . 5

Soil Water . . . . . . . . . . . . 7

Soil Heating . . . . . . . . . . . . . 7

Root Kill ................ . . 7

RESULTS AND DISCUSSION . . . . . . . . . . . . 7

Prescribed Fires . . . . . . . . . . . 7

Duff Water .. . . . . . . . . . . . . 9

Soil Water . . . . . . . . . . . . . 10

Soil Temperatures . . . . . . . . . . . . . 11

Root Mortality ................. 11

MANAGEMENT APPLICATION .............. . 12

PUBLICATIONS CITED . . . . . . . . . . . . . . 13

Use of trade or firm names is for reader information only, and does not constitute endorsement by the U.S. Department of Agriculture of any commercial product or service. 


\section{RESEARCH SUMMARY}

In early September 1975, two clearcuts (14 and 17 acres; 5.7 and 6.9 ha), two sets of 4 small clearcuts ( $<1.5$ acres; 0.6 ha each), and one shelterwood cutting (22 acres; 8.9 ha) were broadcast burned principally for seedbed preparation and fuel reduction on the Coram Experimental Forest. The objective was to develop a model for predicting duff reduction (amount and percent) and mineral soil exposure (percent) resulting from the fires, using only preburn measurements for inputs. In addition, the influence of the fires on soil heating, soil water content, and nonconiferous root mortality was quantified.

Because of the relatively low maximum air temperatures and high precipitation on the study area during August, the fuels were relatively moist at the time of ignition. As a result, the fires generally spread poorly, especially in the shelterwood, except wherethe fuels were concentrated. The prescribed fires reduced the duff an average of 27 percent in the clearcuts and 11 percent in the shelterwood. Mineral soil exposure averaged 19 percent in the clearcuts and 10 percent in the shelterwood. The amount of water within the upper 4 inches $(10.2$ $\mathrm{cm}$ ) of soil was not changed greatly, there was no significant heating of the surface soil above $113^{\circ} \mathrm{F}\left(45^{\circ} \mathrm{C}\right)$, and root mortality was low.

Multivariate regression analysis was used to derive prediction equations for duff reduction and mineral soil exposure. However, because of extremely poor correlation between the dependent variables, duff reduction and mineral soil exposure, and all combinations of the independent variables, no statistically valid equations resulted. The expected correlation between duff consumption and lower duff water content was not evidenced. This was attributed to the high water content of the duff itself, which averaged nearly 150 percent in the three blocks studied. These results substantiate Shearer's (1975) conclusions. Broadcast burning for seedbed preparation should not be attempted in this forest type when lower duff water contents exceed about 100 percent. 


\section{INTRODUCTION}

Natural seeding is normally the preferred method of regenerating conifers in the Northern Rocky Mountains (Schmidt and Shearer 1973). Some seedbed preparation is usually necessary for successful natural regeneration. Shade intolerant species such as western larch (Larix occidentalis Nutt.) regenerate best on bare mineral soil.

In northwestern Montana, broadcast burning for seedbed preparation is commonly practiced in western larch--Douglas-fir (Pseudotsuga menziesii var. gZauca [Beissn.] Franco) stands. Prescribed fire is preferred over mechanical scarification because: (1) it normally costs less (Boyd and Deitschman 1969); (2) it recycles nutrients back into the soil, ultimately resulting in increased tree growth rates (western larch trees up to 13 years old grew about one-third faster on broadcast burned areas than on dozer scarified seedbeds (Schmidt 1969); and (3) it is usually the most practical method for site preparation on steep slopes.

The amount of seedbed preparation desired (or achieved) is best expressed by mineral soil exposure. However, no conclusive quantitative data on the spatial distribution of mineral soil exposure by broadcast burning are available. Instead, research has generally focused on measurements of duff layer consumption. The postfire seedbed condition can be more meaningfully expressed by an estimate of both duff reduction and the spatial distribution of exposed mineral soil. Research has not provided adequate guides for managers to prescribe fires that expose a specified percent of mineral soil. A method is needed to simply and accurately predict the quality of seedbed preparation by burning.

The study reported here is part of a Research and Development Program evaluating alternative residue utilization and disposal treatments, one of which is burning. The objective of this study was to develop regression equations, using only preburn measurement input, for both duff reduction and the amount of mineral soil exposed by prescribed fire for clearcut and shelterwood silvicultural systems. The prescription goal for the fires was a 2 -inch reduction of the duff layer. This would have resulted in an overall mean duff depth reduction of about 50 percent, and provided the minimum 30 percent mineral soil exposure desired. Prescribed conditions deemed necessary to achieve the objective were as follows:

\section{SHELTERWOOD BLOCK}

$0-1$ inch $(0-2.54 \mathrm{~cm})$ diameter dead fuel water content

Upper duff water content

Wind speed

Air temperature

Relative humidity

Time of day

\section{CLEARCUT BLOCKS}

0-1 inch $(0-2.54 \mathrm{~cm})$ diameter dead fuel water content

Upper duff water content

Windspeed

Relative humidity
RANGE

$$
\begin{aligned}
& 16 \%-18 \% \\
& 40 \%-60 \% \\
& 0-5 \mathrm{mi} / \mathrm{h}(0-8.05 \mathrm{~km} / \mathrm{h}) \\
& 70{ }^{\circ} \mathrm{F}\left(21.1^{\circ} \mathrm{C}\right) \text { or } 1 \text { ess } \\
& 25 \% \text { or above; steady or rising } \\
& 1400 \text { or later }
\end{aligned}
$$

\section{RANGE}

$$
\begin{aligned}
& 12 \%-15 \% \\
& 25 \%-40 \% \\
& 0-10 \mathrm{mi} / \mathrm{h}(16.09 \mathrm{~km} / \mathrm{h}) \text {; } \\
& \text { steady to diminishing } \\
& 25 \% \text { or above, steady or rising }
\end{aligned}
$$


In addition, the influence of the prescribed fires on soil heating, soil water content, and root mortality of nonconifers was estimated. These data provided an estimate of the amount of mineral soil exposed and a forecast of early vegetative competition.

\section{LITERATURE}

Research on duff consumption has been related to either duff water or to indices of fire danger or drought (Artley 1976). Because measurements of physical parameters (such as duff water content) enhance consistent interpretation over time, and decrease the chance of interpretive error, they are probably more useful in describing duff consumption.

Duff moisture has repeatedly been used in research describing and predicting duff reduction by fire. Early investigations related duff reduction to a subjective estimate of duff moisture content (Sweeny and Biswell 1961; Morris 1966). Later attempts explained duff consumption by precisely measuring the variables thought to be the most important contributors. For example, Hough (1968) and Steele and Beaufait (1969) determined that measurements of the moisture content of the litter, the duff, and the woody fuel, all were useful in predicting duff reduction. More recently, emphasis had shifted to the use of multivariate regression analysis and correlation analysis in order to formulate prediction equations for duff reduction. Van Wagner (1972) found that the best predictor of duff weight consumed by fire in eastern pine stands is duff moisture content and is more closely related to duff consumption than measurements of actual fire behavior.

Similar results have been reported from prescribed fire studies in three different areas within western larch forests of northwestern Montana. Duff consumption is 1 inearly related to the moisture content of the lower half of the duff when it is between the range of approximately 40 to 110 percent (Shearer 1975). Steele (1975) attributed duff consumption to preburn duff depth, duff moisture content, and the weight of the woody shrubs. Norum (1975, 1977) concluded that duff reduction was dependent on the factors above the duff which most influenced fire intensity and persistence, in addition to the moisture content of the lower duff. Van Wagner (1965) also found that mineral soil exposure increased as fire intensity increased. Similarly, Beaufait and others (1977) showed a strong relationship between the water loss from a water can analog (Beaufait 1966; George 1969) and duff consumption. In addition, they concluded that duff reduction by fire was a function of the moisture content of the upper half of the duff.

\section{STUDY AREA AND TREATMENT}

The study was conducted on the 7,460 acre (3,019 ha) Coram Experimental Forest, on the Flathead National Forest, in northwestern Montana (fig. I). The study sites are located below the main ridge facing east into Abbot Basin (lat. $48^{\circ} 25^{\prime} \mathrm{N} .$, long. $^{\circ}$ $113^{\circ} 59^{\prime}$ W.). Six blocks, consisting of two clearcuts (14 and 17 acres; 5.7 and 6.9 ha), two shelterwoods ( 35 and 22 acres; 14.2 and 8.9 ha), and two sets of eight small clearcuts (average 0.8 acre; 0.3 ha, range from 0.3 to 1.4 acres; 0.1 and 0.6 ha), were 


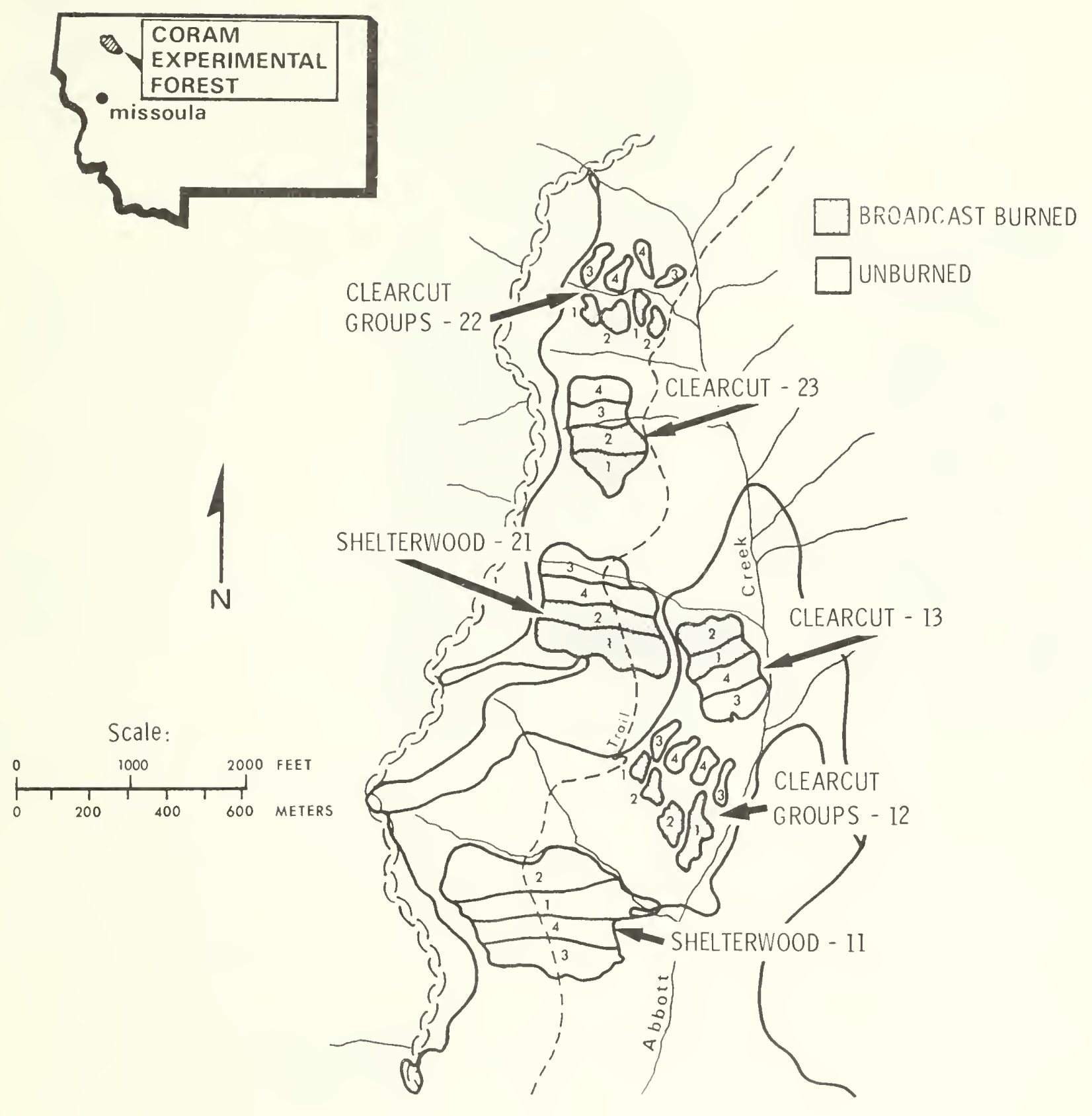

Figure 1.--Location of cutting blocks in Abbot Basin, Corom Experimental Forest. mimber hamested in 1974 and broadcast bumed in sept. 1975. 
Eigure 2.--Prescribed broadcast burning of clearcut 13 on Coram Experimental Eorest. only half of each cutting was bumed.

logged in 1974. Each block was further divided into four subblocks, in which four different standards of timber and residue utilization were employed (fig. 1). Of the four subblocks, only No. 1 and 2 were broadcast burned (fig. 2), and this study was limited to them. A description of the two utilization standards applied to the burned subblocks in each block follows:

\begin{tabular}{cl} 
Subblock & \multicolumn{1}{c}{ Trees Cut } \\
1 & $\begin{array}{l}\text { All trees except } \\
\text { designated overstory } \\
\text { shelterwood trees }\end{array}$ \\
2 & $\begin{array}{l}\text { All trees except } \\
\text { designated overstory } \\
\text { shelterwood trees. }\end{array}$
\end{tabular}

Utizization Standard

All material (live and dead, standing and down) to 3 inch $(7.6 \mathrm{~cm})$ dia., 8 foot $(2.4 \mathrm{~m})$ length, and $1 / 3$ sound removed.

Sawtimber material (live and recently dead) to 1974 Forest Service standards: 7 inch $(17.8 \mathrm{~cm})$ d.b.h., 8 foot $(2.4 \mathrm{~m})$ length, and $1 / 3$ sound removed.

The timber type on the study area is 1arch--Douglas-fir (Cover Type 212, Society of American Foresters 1954). This type is composed primarily of western larch and Douglas-fir. Associated species include subalpine fir (Abies Zasiocarpa [Hook.] Nutt.) 
and Engelmann spruce (Picea engelmannii Parry). The study area falls primarily in the Abies lasiocarpa/Clintonia uniflora habitat type, with the following phases represented: Aralia nudicaulis, Menziesia fermiginea, Clintonia uniflora, and XerophylZum tenax (Pfister and others 1977; Bernard L. Kovalchik 1974, unpublished data).

The topography ranges in steepness from 30 to 80 percent $\left(17^{\circ}\right.$ to $\left.39^{\circ}\right)$, while the elevation ranges from 3,900 to 5,200 feet $(1,189$ to $1,585 \mathrm{~m}) \mathrm{m} . \mathrm{s} .1$. The soils on the slopes are derived from impure limestone and underlying material of loamy-skeletal soil families (Klages and others 1976).

\section{METHODS}

Before logging, 10 permanent points were systematically located at 100-foot intervals within each of the subblocks in the clearcut and shelterwood cuttings. Five points were located within each of the eight small clearcuts at variable intervals depending on size of the opening. All plots were referenced to these points.

\section{Duff Reduction and Mineral Soil Exposure}

Fifty 4 by $4 \mathrm{ft}(1.2$ by $1.2 \mathrm{~m})$ plots were randomly located in each subblock (five referenced to each permanent point), of the shelterwood and clearcut blocks (none were established in the small clearcuts). At each plot the following preburn measurements were taken (fig. 3).

1. Duff depth (not including the litter layer)

2. Mineral soil exposure (percent of area)

3. Weight per unit of area of downed woody material in each of the following size classes (Brown 1974):
a. 0-0.25 inch $(0-0.64 \mathrm{~cm})$ diameter
b. $0.25-1.00$ inch $(0.64-2.54 \mathrm{~cm})$ diameter
c. 1-3 inch $(2.54-7.62 \mathrm{~cm})$ diameter
d. Greater than 3 inch $(7.62 \mathrm{~cm})$ diameter, sound
e. Greater than 3 inch $(7.62 \mathrm{~cm})$ diameter, rotten.

4. Woody shrub weight (Brown 1976)

5. Depth of down woody material

6. Slope

7. Aspect. 


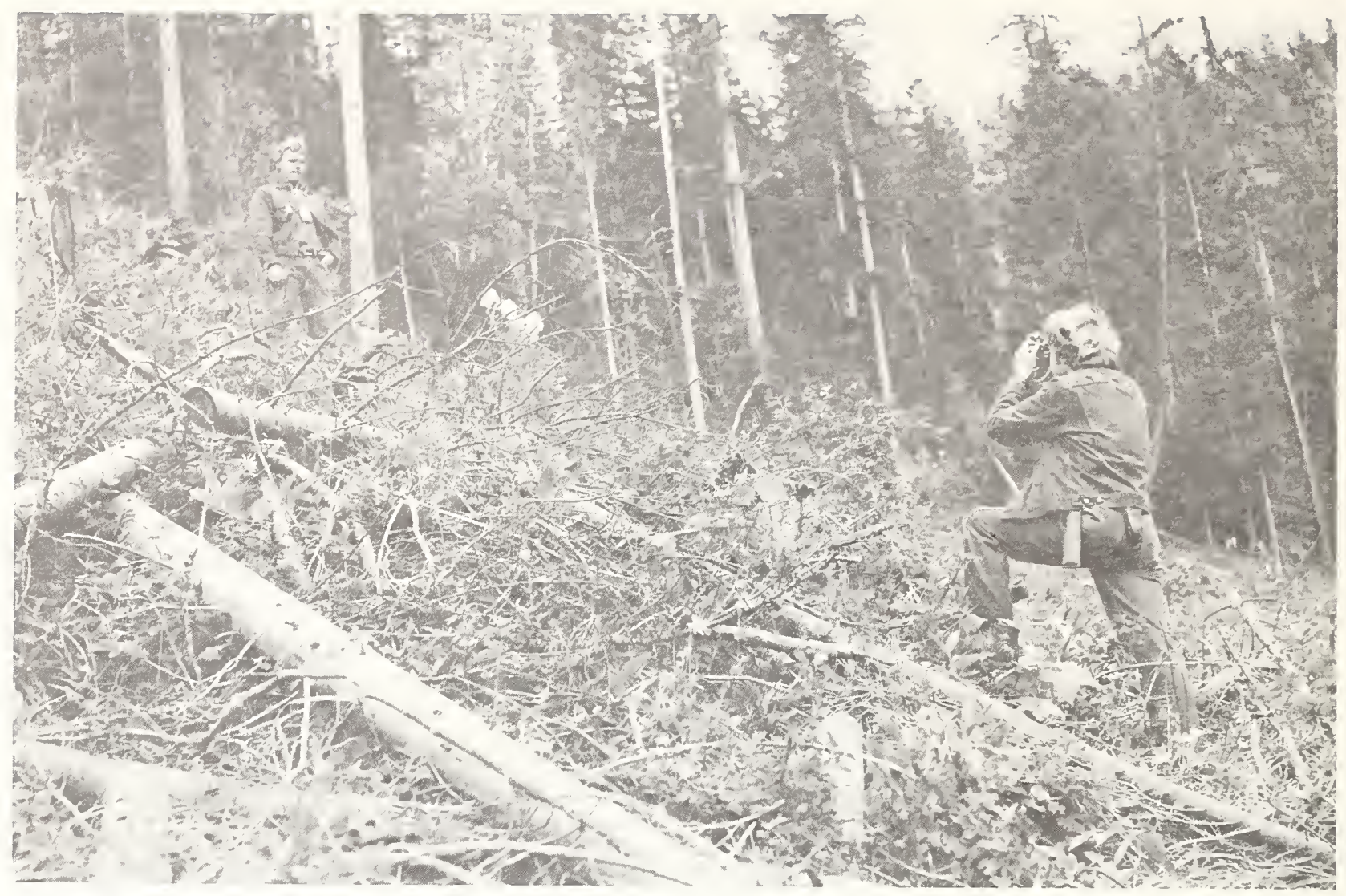

Figure 3.--Preburned slash measurements being taken on clearcut 13, June 26, 1975. Note relatively light fuel volume.

Approximately 1 hour prior to the ignition of each fire, samples of the following material were gathered at each of the permanent points:

1. Duff (upper and lower half sampled separately)

2. Downed woody material in the 0-0.25 inch $(0-0.64 \mathrm{~cm})$ and $0.25-1$ inch $(0.64-2.54 \mathrm{~cm})$ diameter size classes

3. Herbaceous vegetation.

Samples were weighed, dried, and reweighed to determine the preburn water content of each. taken:

After the fires, the plots were relocated and the following measurements were

1. Duff depth

2. Mineral soil exposure (percent of area)

3. Weight per unit area of each of the five diameter size classes of downed woody material

4. Depth of downed woody material.

Each of the preburn measurements was designed as a potential independent variable for a regression analysis on duff reduction and mineral soil exposure. 


\section{Soil Water}

The percent of water (by weight) held within the surface inch of soil was estimated gravimetrically the day of, and the morning after each fire near the 20 permanent points. At 10 of these sampling points soil water was also estimated within the 1 - to 4 -inch $(2.54$ - to $10.16-\mathrm{cm})$ level. The results indicated the amount of water gained through condensation or lost by vaporization as a result of the broadcast fires.

\section{Soil Heating}

The maximum temperature within the upper 6 inches $(15.2 \mathrm{~cm})$ of soil was estimated by using Tempilaq (Tempil Division, Big Three Industries, Inc., South Plainfield, N.J.). Rectangular asbestos strips having six full-length depressions scored on both sides were used. Each depression was filled with Tempilaq of a different melting point between $113^{\circ} \mathrm{F}\left(45^{\circ} \mathrm{C}\right)$ and $500^{\circ} \mathrm{F}\left(246^{\circ} \mathrm{C}\right)$. One strip was referenced to each of the 20 permanent points and the upper edge of each strip was positioned along the soil-duff interface.

\section{Root Kill}

On the day of burning, the numbers of dead and living roots were counted at the same 10 locations where the preburn soil water samples were taken down to the 0 to 4 inch ( 0 to $10.16 \mathrm{~cm}$ ) level. This consisted of exposing a vertical face of soil 10 inches $(25.4 \mathrm{~cm})$ wide and 6 inches $(15.2 \mathrm{~cm})$ deep. This surface was sprayed with orthotolidine solution (Shearer 1975) that indicated which roots were respiring (living). The numbers of 1 iving and dead roots greater than 0.05 inch $(0.13 \mathrm{~cm})$ in diameter at this interface were counted. Living and dead roots were counted again about 2 weeks after burning, near the point where the postfire soil water samples were taken. Both the numbers of dead and living roots were recorded.

\section{RESULTS AND DISCUSSION}

\section{Prescribed Fires}

The burning was accomplished during the period from September 8 through September 13, 1975 (fig. 1 and 4). No block was burned entirely within the prescription established for duff reduction and mineral soil exposure (see p l) because (1) cool, wet conditions prevailed for several weeks prior to burning preventing drying of fuel, and (2) burning could not be postponed for a year due to time requirements imposed on the R\&D Program to complete its overall research objective. Block 11 (shelterwood) was not burned because both the preburn fuel and the duff water samples were above prescription limits (see p. 2). In each of the other units, preburn sampling indicated that the 0.0 to 1 inch $(0.0$ to $2.54 \mathrm{~cm})$ diameter fuels were within prescription limits, while the upper duff water content was consistently too high (table 1). 


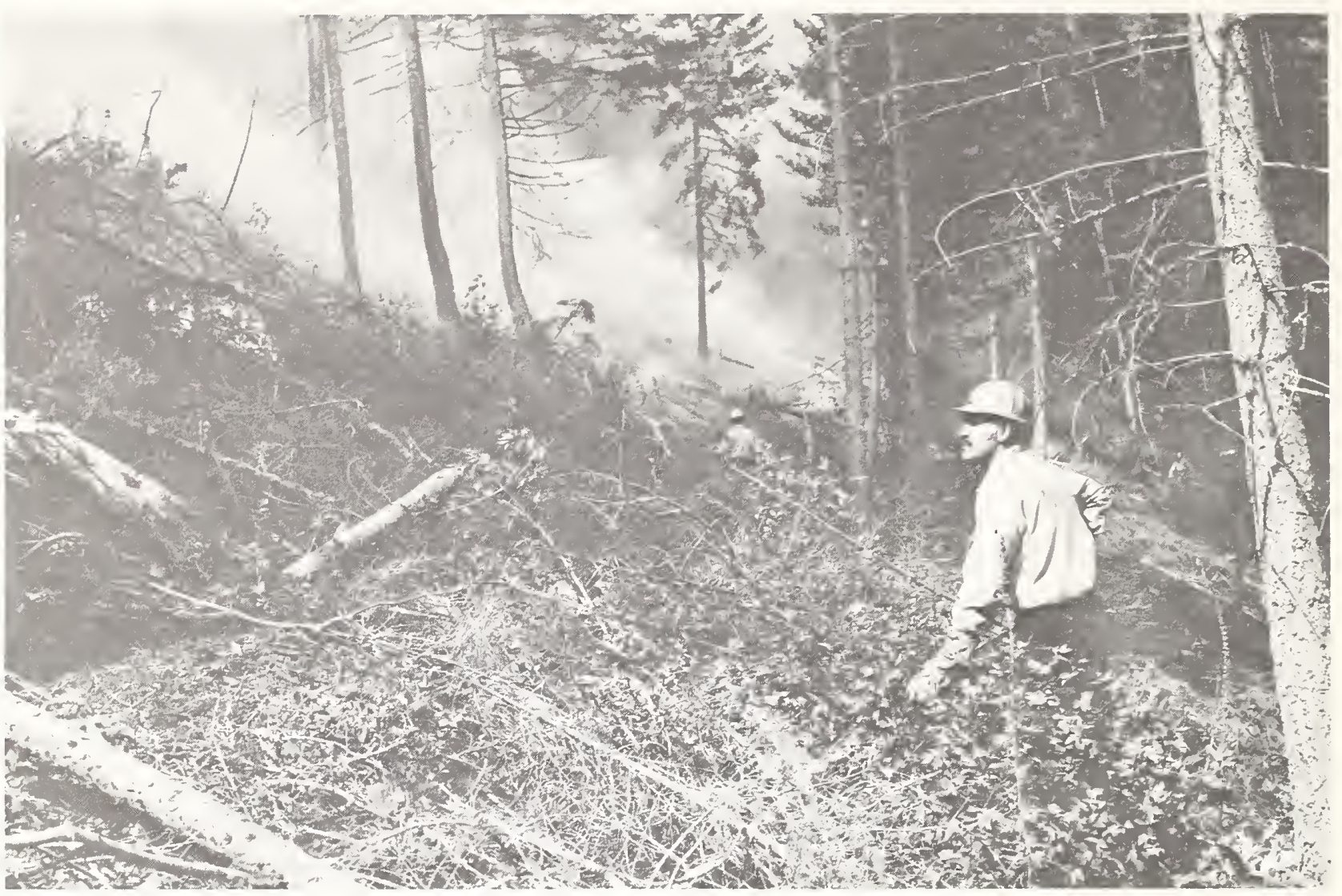

Figure 4.--Prescribed broadcast burning of the sheltemood on Coram Experimental Forest. slash and duff were moist as indicated by little flame and heavy smoke.

Table 1.--Preburn water content ${ }^{l}$ of woody fuels, duff, and herbaceous vegetation.

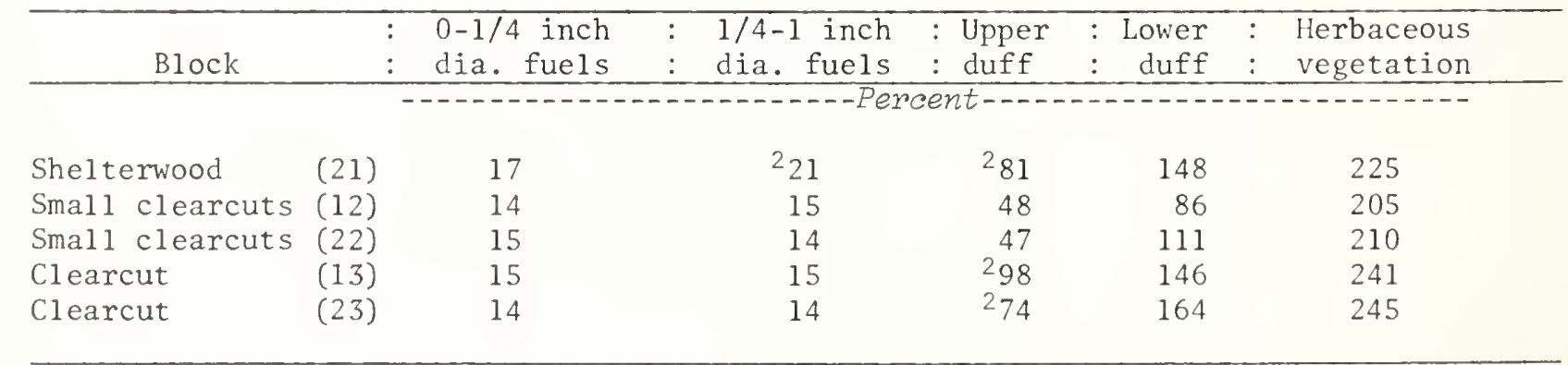

${ }^{1}$ Mean values for 20 sample points.

${ }^{2}$ Above prescription limits (lower duff and herbaceous vegetation limits were not prescribed). 
Table 2.-Mean duff reduction and mineral soil exposure resulting from buming

\begin{tabular}{|c|c|c|c|c|c|}
\hline \multicolumn{2}{|l|}{ Block } & $\begin{array}{c}: \text { Sample } \\
: \quad \text { No. }\end{array}$ & $\begin{array}{l}\text { : Mineral soil } \\
: \quad \text { exposure }\end{array}$ & $:$ Duff reduction & Duff reduction \\
\hline & & & Percent & Inches & Percent \\
\hline Shel terwood & $1(21-1)$ & 40 & 7 & 0.2 & 5 \\
\hline Shel terwood & $1(21-2)$ & 34 & 13 & .5 & 18 \\
\hline Small Clearcuts & $(12)$ & 20 & (2) & 1.1 & 48 \\
\hline Small Clearcuts & $(22)$ & 20 & (2) & .8 & 28 \\
\hline Clearcut & $(13)$ & 91 & 18 & .6 & 27 \\
\hline Clearcut & (23) & 90 & 20 & .7 & 26 \\
\hline
\end{tabular}

${ }^{1}$ Shelterwood subblock mean values were not similar enough statistically to allow the subblocks to be combined.

${ }^{2}$ No data--mineral soil exposure was not estimated.

The fires did not spread well because of frequent fuel discontinuity, especially in subblock 1, which had lighter fuel. Subblock 2 of each block burned more completely and evenly as a result of heavier fuel loading. However, usually only the fine fuels and litter were consumed. Within each block a number of plots did not burn, and these were lost for analysis ( 9 and 10 out of 100 in each of the two clearcuts, and 26 of 100 in the shelterwood).

\section{Duff Reduction and Mineral Soiz Exposure}

Table 2 summarizes the mean duff depth reduction and mineral soil exposure on each subblock. The percentage of mineral soil exposed ranged from a high of 20 percent on clearcut block 23 to a low of 7 percent on shelterwood subblock 21-1, falling short of the 30 percent minimum prescribed. Mean duff depth reduction was less than 0.8 inch $(2.03 \mathrm{~cm})$ in all blocks, amounting to a reduction of approximately 25 percent. The prescription called for a 2 -inch $(5.08-\mathrm{cm})$ reduction to provide for an overall mean duff depth reduction of about 50 percent. Again prescription goals were not met.

These results are primarily attributed to the high water content of the duff layer, especially in the lower half. Upper duff water content was above prescription limits in both the clearcuts and the shelterwood, and except for block 12, lower duff water content exceeded 100 percent in all blocks.

The Rex--Fortran-4 computer program (Grosenbaugh 1967) was used for both combinatorial screening and conventional multivariate regression analysis. Both mineral soil exposure and duff reduction were tested against all possible combinations of independent variables, up to and including sets of four. In all cases, $R^{2}$ values were so low that no relationships were indicated. Various transformations and combinations of variables were also tried with no significant improvements. Therefore, no regression equations are presented.

\section{Duff Water}

The water content of the duff, especially of the lower half, has been repeatediy shown to be a major influence in the reduction of the duff layer by fire (Norum 1975, 1977; Shearer 1975; Van Wagner 1972). However, the results of this study show no relationship between them, because of the magnitude of the water contents. Shearer (1975), working in the same forest type, found that duff reduction in percent is related to lower duff water, only when the latter is between 50 and 110 percent (fig. 5). 


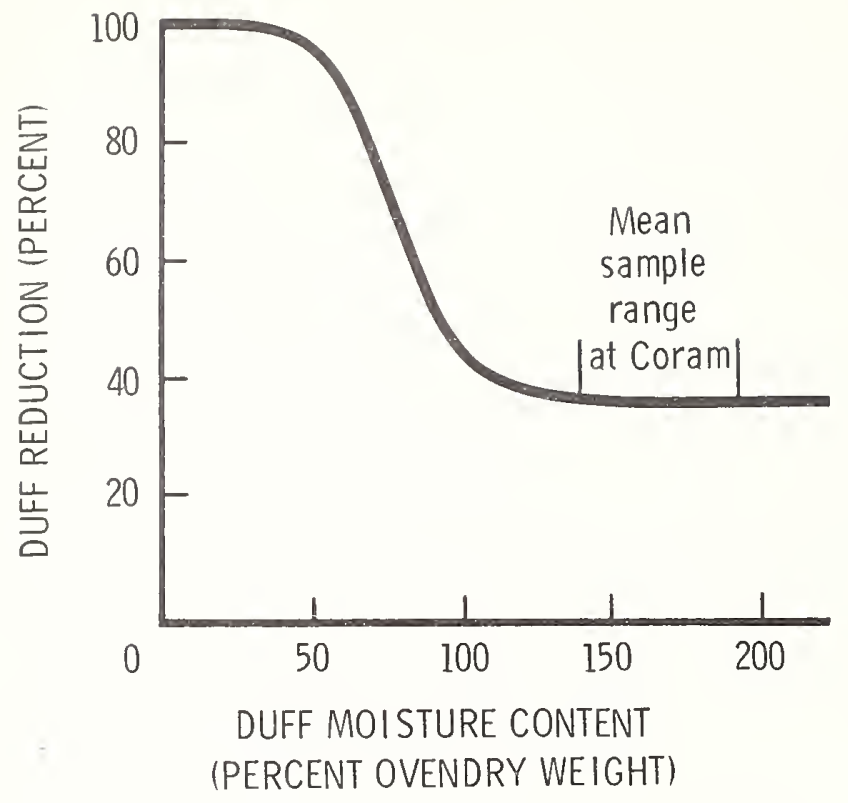

Figure 5.--Duff reduction related to the water content of the lower half of the duff Zayer (from Shearer 1975).

At 50 percent water content, the duff layer is mostly burned off, but as the water content increases, a decreasing percentage of the duff layer is consumed. Above 110 percent, however, duff reduction drops to a uniformly low amount.

When the results of this study are superimposed on Shearer's curve, it is not surprising that lower duff water content had no significant correlation to duff consumption. In the clearcuts, lower duff water averaged 155 percent, with a range from 71 to 275 percent. The shelterwood averaged 148 percent with a range from 77 to 205 percent. The range of the subblock mean lower duff water contents ( 140 to 188 percent) is plotted on figure 5 in order to clearly show that the conditions as sampled were outside of the predictive portion of the curve.

The unusually high duff moisture resulted from the high precipitation and low temperature on the Coram Experimental Forest during August 1975, the month preceding the fires. During that month there was a total of 4.07 inches $(10.34 \mathrm{~cm})$ of precipitation, twice the normal mean, and the average daily maximum temperature was $66.9^{\circ} \mathrm{F}$ $\left(19.3^{\circ} \mathrm{C}\right)$, approximately $2^{\circ} \mathrm{F}\left(1.2^{\circ} \mathrm{C}\right)$ below normal. This was the coldest August ever recorded at the Hungry Horse Dam, and the third wettest since records were started in 1947.

\section{Soil Water}

None of the prescribed fires greatly changed the amount of water within the surface 4 inches $(10.16 \mathrm{~cm})$ of soil; within the upper inch $(2.54 \mathrm{~cm})$, the average was 27.1 percent before, and was 26.8 percent after fires. Of the 398 samples taken within the surface inch during the week of burning, 63 percent contained 20 to 30 percent water, while 15 percent contained less than 20 percent water and 22 percent contained greater than 30 percent water. Nearly half of the samples within the surface inch increased in water following burning, probably indicating a zone of condensation similar to that described by Uggla (1973).

The amount of water within the surface inch of soil varied significantly by cutting method. The average amount of water was least within the shelterwood cutting, intermediate within the small clearcut groups, and greatest within the clearcuts. In addition, the average amount of water increased (but not significantly) with greater elevation by type of cutting. 
The surface inch of soil had slightly, but significantly, higher water content under heavier concentrations of slash, probably because of less evaporation from the soil due to greater shading. Soil water averaged 28 percent under heavy slash and 26 percent under 1 ight slash.

\section{Soil Temperatures}

Prescribed fires caused little heating within the surface soil (table 3 ). The clearcuts and groups of small clearcuts burned more completely than the burned shelterwood cutting. Soil heating was greatest at the soil surface on block 23 (upper clearcut), where 60 percent of the sample points reached at least $113^{\circ} \mathrm{F}\left(45^{\circ} \mathrm{C}\right)$; only 20 percent of these points reached $138^{\circ} \mathrm{F}\left(58.9^{\circ} \mathrm{C}\right.$ ) (near the lethal temperature for living plant tissue). The greatest depths that reached $113^{\circ} \mathrm{F}\left(45^{\circ} \mathrm{C}\right)$ and $138^{\circ} \mathrm{F}\left(58.9^{\circ} \mathrm{C}\right)$ were 2.4 inches $(6.10 \mathrm{~cm})$ and 1.4 inches $(3.56 \mathrm{~cm})$, respectively. Rarely did the surface soil reach $200^{\circ} \mathrm{F}\left(93.3^{\circ} \mathrm{C}\right)$.

\section{Root Mortality}

Low soil warming associated with the prescribed fires caused low root mortality, even within the surface 1 inch of soil (table 4). Least root mortality occurred under the shelterwood cutting where much of the block failed to burn. Because of the low root mortality near the surface, recovery of perennial plants from root sprouts was prolific in 1976 on all burned areas.

Table 3.-Maximum and average soil depth that reached on exceeded three temperatures as estimated by Tempilaq melt during prescribed fires, September 1975, Coram Experimental Forest

\begin{tabular}{|c|c|c|c|c|c|c|c|c|c|c|c|c|c|}
\hline \multirow[b]{2}{*}{ Block } & & \multirow{2}{*}{$\begin{array}{l} \\
: \\
\end{array}$} & \multirow{2}{*}{$\begin{array}{l}\text { Sample } \\
\text { points } \\
\text { burned } 1\end{array}$} & \multicolumn{3}{|c|}{$113^{\circ} \mathrm{F}$} & \multicolumn{3}{|c|}{$138^{\circ} \mathrm{F}$} & \multicolumn{4}{|c|}{$200^{\circ} \mathrm{F}$} \\
\hline & & & & $\operatorname{Max}$ & : Ave & Points & $\operatorname{Max}$ & : Ave & : Points & $\operatorname{Max}$ & : Ave & $:$ & Points \\
\hline & & & Percent & $--I n$ & ches- & Percent & $-\cdots$ Inc & hes-- & Percent & $--I n$ & ches- & & Percent \\
\hline Shel terwood ${ }^{2}$ & $(11)$ & & 0 & -- & -- & - & -- & -- & -- & $-\infty$ & -- & & -- \\
\hline Shelterwood & $(21)$ & & 30 & 1.3 & 0.1 & 10 & 0.6 & $<0.1$ & 10 & 0.0 & 0.0 & & 0 \\
\hline Sma11 Clearcuts & (12) & & 85 & 1.4 & .2 & 45 & .6 & .1 & 20 & .2 & $<.1$ & & 5 \\
\hline Small Clearcuts & $(22)$ & & 85 & .0 & .0 & 0 & .0 & .0 & 0 & .0 & .0 & & 0 \\
\hline Clearcut & (13) & & 100 & .8 & .2 & 55 & .3 & $<.1$ & 15 & .0 & .0 & & 0 \\
\hline Clearcut & (23) & & 90 & 2.4 & .3 & 60 & 1.4 & .1 & 20 & .2 & $<.1$ & & 5 \\
\hline
\end{tabular}

\footnotetext{
${ }^{1}$ Twenty points sampled in each block.

${ }^{2}$ Shelterwood block 11 not burned.
}

Table 4.--Mortality of nonconifer roots (percent) in the surface inch of soit, before and after prescribed burming, by cutting method, Coram Experimental Forest 1975

\begin{tabular}{llc}
\hline & $:$ Living roots $:$ Mortality \\
Cutting method & $:$ Before $:$ After $:$ & (difference) \\
\hline
\end{tabular}

$\begin{array}{lllrr}\text { Shel terwood } & (11) & 90 & 1 & 1- \\ \text { Shelterwood } & (21) & 82 & 76 & 6 \\ \text { Smal1 clearcuts } & (12) & 95 & 69 & 26 \\ \text { Smal1 clearcuts } & (22) & 88 & 50 & 38 \\ \text { Clearcut } & (13) & 80 & 44 & 36 \\ \text { Clearcut } & (23) & 92 & 76 & 16\end{array}$

${ }^{1}$ Not burned. 


\section{MANAGEMENT APPLICATION}

The broadcast burning of moist fuels produces large variation in duff depth reduction and mineral soil exposure, even across relatively similar areas. Because mean values were small, standard deviations for each consistently approached the means in the clearcut, and exceeded them in the shelterwoods. Differences in variation were found to be primarily within each block rather than between blocks. In addition, the fires failed to heat or to dry the surface soil sufficiently to significantly reduce the root sprouting potential of competing nonconiferous species.

The hypothesis that the high water content of the duff influenced the expected relationships is strengthened when weather patterns for the area are examined. Although August 1975 was the coldest and one of the wettest on record, this combination of a low temperature with heavy precipitation has occurred in this area seven times in the past 29 years. Because this situation occurs about one year out of four, the possibility of extremely wet duff conditions should be considered when planning September fires.

The lack of correlation between lower duff water content and percent duff reduction substantiates Shearer's (1975) and Norum's (1977) conclusions. Therefore, with a mean lower duff water content of greater than 100 percent, broadcast burning for duff reduction should probably not be attempted in this forest type.

The burned areas revegetated quickly in 1976 from rhizomes, root crowns, and underground stems. Growth was enhanced by the large supply of available nutrients released during the fires. Trees and other vegetation relying on seed for regeneration were at a competitive disadvantage because of the density of plants sprouting from underground parts. Regeneration of shade-intolerant conifers will be difficult because of generally unfavorable seedbed conditions and intense competition for light and water. A few western larch that germinated in 1975 survived within unburned areas and will probably form a part of the dominant tree canopy within a few years. It is doubtful that many other shade-intolerant conifers will survive this competition. Gradually the more shade-tolerant subalpine fir, western hemlock (on lower slope moist sites), and Douglasfir (on drier sites) will establish and complete a new stand. Later papers will discuss (1) development of vegetation (including trees) within each cutting method and residue treatment, and (2) effects of broadcast fires on residual trees. 


\section{PUBLICATIONS CITED}

Artley, Donald K.

1976. Predicting duff reduction from broadcast burning in western larch--Douglas-fir

stands. M.S. Thesis, Sch. For., Univ. Mont., Missoula, $72 \mathrm{p}$.

Beaufait, William R.

1966. An integrating device for evaluating prescribed fire. For. Sci. 12(1):27-29.

Beaufait, William R., Charles E. Hardy, and William C. Fischer.

1977. Broadcast burning in larch-fir clearcuts: the Miller Creek-Newman Ridge study.

USDA For. Serv. Res. Pap. INT-175, rev., 53 p. Intermt. For. and Range Exp. Stn.,

Ogden, Utah.

Boyd, R. J., and G. H. Deitschman.

1969. Site preparation aids natural regeneration in western larch-Engelmann spruce

strip clearcuttings. USDA For. Serv. Res. Pap. 1NT-64, 10 p. Intermt. For. and

Range Exp. Stn., Ogden, Utah.

Brown, James $K$.

1974. Handbook for inventorying downed woody material. USDA For. Serv. Gen. Tech.

Rep. INT-16, 24 p. Intermt. For, and Range Exp. Stn., Ogden, Utah.

Brown, James $K$.

1976. Estimating shrub biomass from basal stem diameters. Can. J. For. Res. $6: 153-158$.

George, Charles Willard.

1969. A water-can fire analog--its thermal characteristics and calibration. M.S.

Thesis. Sch. For., Univ. Mont., Missoula, 144 p.

Grosenbaugh, L. R.

1967. REX--Fortran-4 system for combinatorial screening or conventional analysis of

multivariate regressions. USDA For. Serv. Res. Pap. PSW-44, 47 p. Pac. Southwest

For. and Range Exp. Stn., Berkeley, Calif.

Hough, W. A.

1968. Fuel consumption and fire behavior of hazard reduction burns. USDA For. Serv.

Res. Pap. SE-36, 7 p. Southeast For. Exp. Stn., Asheville, N.C.

Klages, M. G., R. C. McConne11, and G. A. Nielsen.

1976. Soils of the Coram Experimental Forest. Mont. Agric. Exp. Stn. Res. Rep. 91, $43 \mathrm{p}$.

Morris, W. G.

1966. Guidelines offered for slash burning. For. Ind. 93(10):62-63.

Norum, Rodney A.

1975. Characteristics and effects of understory fires in western larch/Douglas-fir stands. Ph.D. Diss., Sch. For., Univ. Mont., Missoula, 155 p.

Norum, Rodney A.

1977. Preliminary guidelines for prescribed burning under standing timber in western 1 arch/Douglas-fir forests. USDA For. Serv. Res. Note 1NT-229, 15 p. Intermt. For. and Range Exp. Stn., Ogden, Utah.

Pfister, Robert D., Bernard L. Kovalchik, Stephen F. Arno, and Richard C. Presby.

1977. Forest habitat types of Montana. USDA For. Serv. Gen. Tech. Rep. INT-34,

174 p. Intermt. For. and Range Exp. Stn., Ogden, Utah. 
Schmidt, Wyman C.

1969. Seedbed treatments influence seedling development in western larch forests. USDA For. Serv. Res. Note INT-93, 7 p. Intermt. For. and Range Exp. Stn., Ogden, Utah.

Schmidt, Wyman C., and Raymond C. Shearer.

1973. Western larch. In: Silvicultural systems for the major forest types of the United States, p. 37-38. U.S. Dep. Agric., Agric. Handb. 445.

Shearer, Raymond C.

1975. Seedbed characteristics in western larch forests after prescribed burning.

USDA For. Serv. Res. Pap. INT-167, 26 p. Intermt. For. and Range Exp. Stn., Ogden, Utah.

Society of American Foresters, Committee on Forest Types.

1954. Forest cover types of North America (exclusive of Mexico). 67 p. Washington, D.C.

Steele, Robert $W$.

1975. Understory burning in larch--Douglas-fir forests as a management tool.

Ph.D. Diss., Sch. For., Colo. State Univ., Fort Collins, 109 p.

Steele, Robert $W$. , and William R. Beaufait.

1969. Spring and autumn broadcast burning of interior Douglas-fir slash. Mont. For. and Conserv. Exp. Stn. Bull. 36, $12 \mathrm{p}$.

Sweeny, James R., and Harold H. Biswell.

1961. Quantitative studies of the removal of litter and duff by fire under controlled conditions. Ecology 42(3):572-575.

Uggla, Evald.

1973. Fire ecology in Swedish forests. Tall Timbers Fire Ecology Conf. Proc. 13:171-190.

Van Wagner, C. E.

1965. Prescribed burning experiments in red and white pine. Can. Dep. For. Publ. $1020,27 \mathrm{p}$.

Van Wagner, C. E.

1972. Duff consumption by fire in eastern white pine stands. Can. J. For. Res. $2(1): 34-49$. 
Artley, Donald K., Raymond C. Shearcr, and Robcrt W. Steele.

1978. Effects of burning moist fuels on seedbed preparation in cutover western larch forests. USDA For. Serv. Res. Pap. INT -211, 14 p. Intermt. For. and Range Exp. Stn., Ogden, Utah 84401.

Two large clearcuts, eight small clearcuts, and one large shelterwood cutting in a larch-fir forest in northwestern Montana were broadcast burned following alternative residue utilization and disposal treatments. The fires failed to substantially reduce the duff or expose much mineral soil beeause of low maximum temperatures and high precipitation prior to burning. Changes in soil water, soil heating, and root mortality associated with the fires were minimal.

KEYWORDS: prescribed burning, western larch, duff reduction, fire use, seedbed prcparation, soil heating, moisture content.

Artley, Donald K., Raymond C. Shearer, and Robert W. Steele.

1978. Effects of burning moist fuels on seedbed preparation in cutover western larch forcsts. USDA For. Serv. Res. Pap. INT -211, 14 p. Intermt. For. and Range Exp. Stn., Ogden, Utah 84401.

Two large clearcuts, eight small clcarcuts, and one large shelterwood cutting in a larch-fir forest in northwestern Montana were broadcast burned following alternative residue utilization and disposal treatments. The fires failed to substantially reduce the duff or expose much mineral soil because of low maximum temperatures and high precipitation prior to burning. Changes in soil water, soil heating, and root mortality associated with the fires were minimal.

KEYWORDS: prescribed burning, western larch, duff reduction, fire use, seedbed preparation, soil heating, moisture content. 
Headquarters for the Intermountain Forest and Range Experiment Station are in Ogden, Utah. Field programs and research work units are maintained in:

\section{Billings, Montana}

Boise, Idaho

Bozeman, Montana (in cooperation with Montana State University)

Logan, Utah (in cooperation with Utah State University)

Missoula, Montana (in cooperation with University of Montana)

Moscow, Idaho (in cooperation with the University of Idaho)

Provo, Utah (in cooperation with Brigham Young University)

Reno, Nevada (in cooperation with the University of Nevada) 


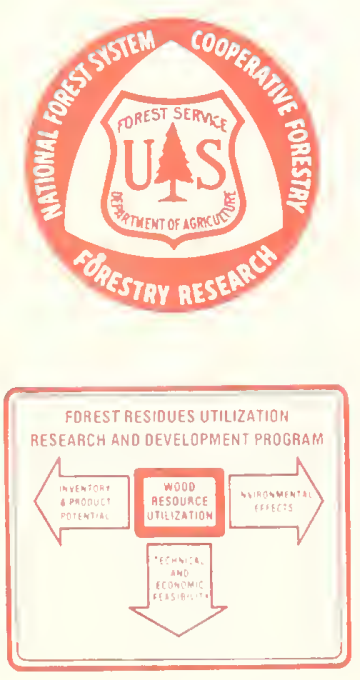